\title{
Law and Letters: A Detailed Examination of David Hoffman's Life and Career
}

\author{
Bill Sleeman•
}

\section{Introduction}

David Hoffman (1784-1854) has been cast as America's first legal ethicist, ${ }^{1}$ as the founder of America's first original method of legal instruction, ${ }^{2}$ as a social critic $^{3}$ and as a land speculator. ${ }^{4}$ His academic interests and publishing efforts ran from legal scholarship ${ }^{5}$ to religious history. ${ }^{6}$ While each of these aspects of his career is interesting in its own right, little effort has been made to look at Hoffman's life and career as a whole. ${ }^{7}$ Despite his talents Hoffman's career was hampered by his difficult personality that often put him at odds with those who were best in a position to help him. This led to frustration on Hoffman's part and bemused tolerance for his peculiarities on the part of his colleagues and friends. Nevertheless his influence on legal education remains strong. This article will review in individual sections the many facets of Hoffman's life and career in an effort to provide a more complete picture than has previously existed.

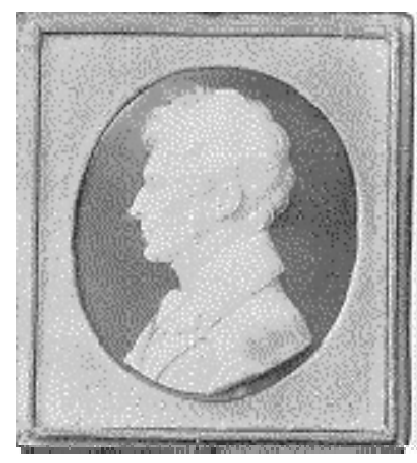

David Hoffman (Eugene Cordell. History of the University of Maryland, 1907) 


\section{Early Years}

Not a great deal is known about Hoffman's youth. His father, Peter Hoffman, was a successful merchant who, when not expanding the family mill works, was active in Baltimore and Maryland politics. ${ }^{8}$ As the youngest son in a family of eleven children, of one of Baltimore's merchant elite, (another brother, Peter, was one of the founders of the Baltimore and Ohio Railroad) David Hoffman grew up in a world that was filled with educational opportunities beyond those available to other young men and the expectation on the part of his family that he would use his education and position to improve his community. ${ }^{9}$

David Hoffman received his college education at St. John's College in Annapolis where he completed the traditional classics based studies in 1802 but left before taking his degree, claiming that the method of education was insufficient for his needs. ${ }^{10}$ After leaving St. John's, Hoffman set about obtaining his legal instruction. Although Hoffman makes no mention of where he gained his American legal training it is probable that he "read" the law in a local practitioner's office and then was presented before the Maryland bar after a period of apprentice like training. This was the sole method of acquiring legal training in early nineteenth century America but for Hoffman it offered little intellectual stimulation, a fact lamented by many of his contemporaries. ${ }^{11}$ This lack of an intellectual content to his own legal education contributed to Hoffman's desire to create a new method of legal education. ${ }^{12}$ Sometime after completing his apprenticeship Hoffman left Baltimore for London where he planned to study law more thoroughly. ${ }^{13}$ Hoffman's desire to learn and to teach would continue throughout his life and eventually he would be granted honorary degrees for his contributions to legal education from both Oxford University and the University of Gottingen in Germany. $^{14}$

\section{A Course of Legal Study - 1817 and beyond}

In 1817 Hoffman presented to Baltimore publisher John Coale the lengthy synthesis of Anglo- 
American legal scholarship that had been occupying his life outside the courtroom. This Course of Legal $\underline{\text { Study }}^{15}$ quickly became one of the most celebrated outlines of formal legal instruction in the United States. ${ }^{16}$ The program was developed with the goal of instituting what Hoffman hoped would be an integrated study of legal thought, philosophy and scientific method to be employed at the recently established University of Maryland (1812). ${ }^{17}$

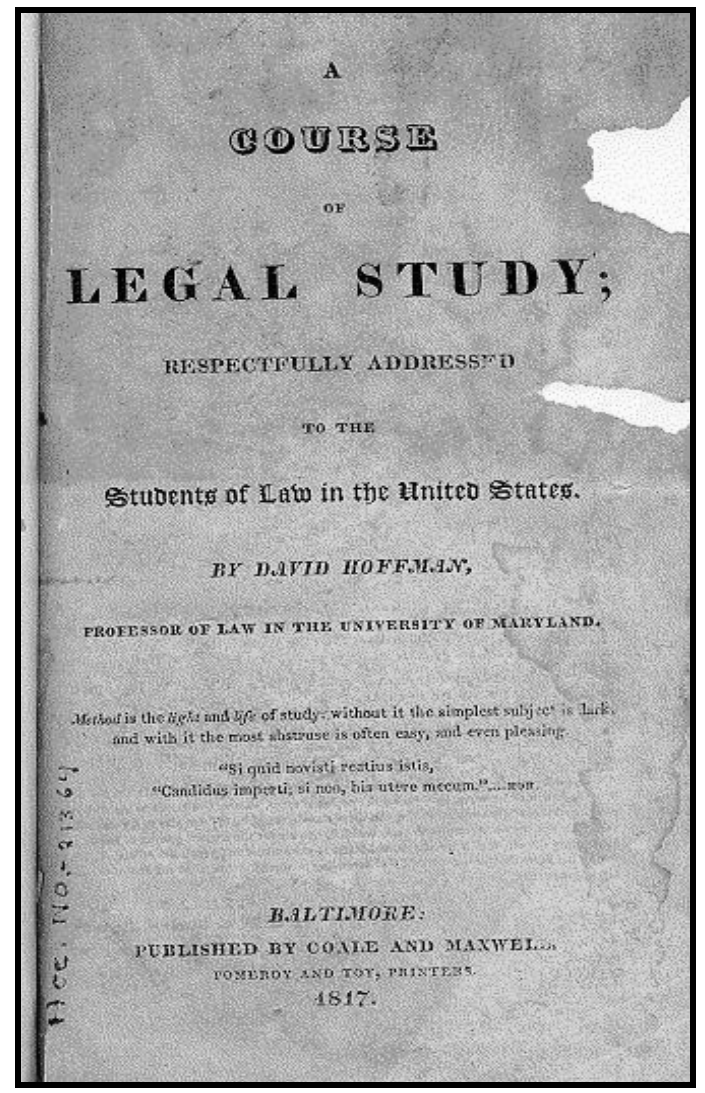

A Course of Legal Study, 1817. (Thurgood Marshall Law Library, Special Collections)

Hoffman's emphasis on detailed study was not unique for its time; the application of a systematic methodology to both formal and private intellectual endeavors had already become common in the early 19th century. ${ }^{18}$ What was truly original however was his effort to create a system for studying the law and liberal arts as interrelated subjects. This goal is illustrated in the introduction to his 1825 lecture wherein Hoffman urges his listeners to consider the relationship of "metaphysicks, ethicks and natural law...and how intimately akin they are to the proper studies of the accomplished lawyer."19 Hoffman's professional experience had left him with the sense that most of his fellows at the bar, as well as American legislators, 
lacked the educational opportunities necessary to be successful members of the legal community. ${ }^{20}$ His 1817 course and subsequent efforts were designed to answer this need by offering both practitioners and students alike the chance to acquire a deeper understanding of law, law making and natural philosophy. The method would, he wrote, "reclaim the time and labour thus often and unprofitably expended" by law students who chose other methods of approaching the subject, and would lead by its application to a more organized and more scholarly system of law in the United States. ${ }^{21}$

Like many legal critics in the early 19th century Hoffman believed that it was only through proper philosophical training that lawyers would obtain the skills needed to help them rise above the pragmatic needs of day-to-day practice. ${ }^{22}$ Even so, Hoffman realized that his thirteen "titles" and four "auxiliary subjects" would demand a great investment of time and commitment from students and he attempted to make the demands of his course more palatable by reminding his potential audience, which doubtlessly included practitioners, that their efforts would produce not only a better lawyer but better personal habits:

Notwithstanding the seemingly great extent of this course, (and certainly we cannot flatter the student with the hope of mastering it with the degree and kind of attention which is usually bestowed on it) let him not be discouraged. What necessarily proves difficult to the desultory and immethodical reader, who comes to his books in the intervals of idleness or dissipation only, and resumes with reluctance what is willingly abandoned on the first call of pleasure, or the first apology of relaxation, may, by a temporary exertion of method and attention, be converted first into a habit, and eventually into a pleasure. ${ }^{23}$

Sticking to the course of study despite the hardships it presented was paramount, in Hoffman's view, if the student were to succeed. However, the student should not be so possessed of a "zeal for study" that he would be caused "to neglect the interests of the few clients they may have. ${ }^{24}$ Financial concerns were never far from Hoffman's mind during this period and would remain a concern throughout his career.

Title Eleven of Hoffman's 1817 work which deals with the laws of the United States provides a ready example of what he saw as the essential components of American law. In this portion he included as readings 
sections of the Federalist, John Adam's Defence of the Constitutions of the Government of the United States, and Marbury v. Madison. ${ }^{25}$ While his selections are tilted towards political jurisprudence, they clearly reflect the ideals to which Hoffman thought lawyers and legislators ought to be trained in and to which they should aspire.

\section{The University of Maryland}

In 1817, three years after securing his appointment as a Professor of Law, Hoffman undertook to have his methodology for teaching law introduced at the University of Maryland. ${ }^{26}$ The University, which had been chartered in 1812 , was essentially a private corporation controlled by the medical faculty. Though the enabling legislation called for the creation of a law program, a theology school and a college of arts and sciences support for these programs depended upon the interest of the medical department. Despite the General Assembly's willingness to pass legislation authorizing a lottery to raise money for a law program at the University, events moved slowly. ${ }^{27}$ During most of the University's early years Hoffman was the only member of the law faculty to devote his full attention and time to the institution. It was not until 1822 and the death of Judge Walter Dorsey, who had been the head of a competing, private law program in Baltimore City, that Hoffman's goal of expanding his Law Institute at the University was realized. ${ }^{28}$

Once Hoffman began his series of lectures at the University of Maryland, almost eight years after he had first approached the faculty, things did not go as he had hoped. ${ }^{29}$ The changing environment at the University did not prove to be to the liking of the ever mercurial scholar, who often seemed to be at odds with someone in the university community - either faculty or trustees. The faculty minutes of 1829 provide one example of this. Hoffman, who was then serving as Secretary of the Faculty, called an emergency meeting of all medical and law faculty to discuss the methodology being used to teach in the College of Arts and Sciences. Hoffman had learned that someone was not teaching by lecture but relying instead on readings and discussion! This was, in Hoffman's view, a direct violation of the University's charter. Intriguingly, Hoffman's position was at odds with the complaints he raised in 1826 in a letter to the Trustees wherein he 
argued strongly for the need for more than just lectures to be included in legal education. ${ }^{30}$ After lengthy debate, the issue of instruction methods was tabled until the faculty committee that had been charged two years earlier with creating by-laws for the university produced a final product - this committee, as most of the faculty was aware, had long been chaired by Hoffman. ${ }^{31}$

Here one gets a glimpse into Hoffman's sometimes self-righteousness approach to dealing with people and situations that did not meet his standards of behavior. To Hoffman, his view was the only one that mattered. Had Hoffman taken the time to discuss his concern with some of his colleagues he might have discovered that the issue was not as great a concern to them as he thought it was, although that is no indication that he would not still have called the meeting. Still, had Hoffman taken a more politic approach he could have avoided the pointed rebuke from Dr. Davidge regarding the unfinished business of Hoffman's By-Laws Committee. ${ }^{32}$

During the late 1820 s and through the 1830 s some medical faculty members pursued the idea of transferring the University from a private corporation to state control. ${ }^{33}$ As word of this effort got out both Hoffman, whose Institute was now firmly established at the University, and Dr. Nathaniel Potter of the Medical School spoke out in opposition to the plan. ${ }^{34}$ By 1835 Hoffman had announced his intention to close the Law Institute and leave the University. ${ }^{35}$ Hoffman's ties to the University were strong however and his name would appear in circulars for the University's law program for several more years. ${ }^{36}$ In 1839 he was persuaded to return and serve on a faculty committee that was charged with drafting a response to the State's efforts to take over the University. ${ }^{37}$

The final cause of Hoffman's decision to leave the University of Maryland remains a mystery. ${ }^{38}$ Based on his published Letter to the Trustees we do know that at least part of his final decision to break with the University was his struggle with the University Trustees and medical faculty over control of the 
University of Maryland and their interference in how his Institute was conducted. Moreover, his financial situation at this point in his life was doubtlessly troubling - Hoffman claimed to have spent $\$ 20,000$ dollars of his own money on the program, an extraordinary sum - if accurate - and one that would have been impossible to recoup from teaching and lecture fees alone. ${ }^{39}$ As the Maryland General Assembly changed the requirements for attorneys to be admitted to practice in the state, interest in his lengthy and expensive course of study dwindled. ${ }^{40}$ This declining enrollment, in a program that seems to have never been very large to begin with, coupled with his already precarious financial situation most certainly played a role in his decision. Finally, legislation passed in 1833 by the General Assembly made it more difficult for attorneys in Maryland to collect outstanding fees from their clients. ${ }^{41}$ For Hoffman this included the University, which according to his Letter to the Trustees, owed him fees for legal work performed on behalf of the school; fees that the Trustees, according to Hoffman, refused to even acknowledge. ${ }^{42}$

Hoffman's decision to depart is made even more troubling by the fact that the Trustees', shortly after his announcement, filed a law suit for the return of furnishings, library books and other materials that Hoffman was entrusted to purchase for the University. ${ }^{43}$ These items, allegedly, were not accounted for at the time of his departure. Although the case was eventually dropped by the Trustees Hoffman's apparent decision to take the material with him reinforces the image of him as impetuous and difficult. ${ }^{44}$ Hoffman may have purchased the material using his own funds or on personal credit, other faculty in the medical school had done the same, yet unlike his fellows on the medical faculty Hoffman decided either not to seek, or not to wait, for reimbursement from the General Assembly of Maryland. ${ }^{45}$

While his plan for legal education did not succeed at the University of Maryland Hoffman never abandoned his efforts to improve the intellectual environment of the legal community. He continued to write and publish his theories, revising his 1817 work in 1836, expanding it into two volumes and even offering an edition published in London for British students. Looking at the 1836 edition it is possible to gauge the 
growth of Hoffman's interests. Now included were "Mr. Story's Commentaries on the Constitution of the United States" while many of the individual constitutional readings by James Wilson (who Hoffman profusely praised in 1817) were moved to the second group of readings in the chapter. New cases that Hoffman added included many of the same cases studied in today's first year Constitutional Law classes: Martin v. Hunter's Lessee (1816), McCulloch v. State of Maryland (1819), Dartmouth College v. Woodward (1819) and Cherokee Nation v. State of Georgia (1836). Perhaps reflecting a change of heart on Hoffman's part he also added Fletcher v. Peck to his list of important cases. Although it was available to him at the time, having been decided in 1810, it was not included in the 1817 edition. ${ }^{46}$ It is likely that this last case, which played a key part in the decision in Dartmouth College, was added by Hoffman after his own legal battles with the University Trustees over the takeover of the University of Maryland.

Hoffman's educational goals for his Institute attracted many of the leading figures of the Maryland bar and at one time or another his faculty included Robert Goodloe Harper, Nicholas Brice, Upton Heath and, briefly, future Chief Justice, Roger B. Taney. ${ }^{47}$ Students who would go on to proclaim the value of Hoffman's method included Maryland Judge George Dobbin ${ }^{48}$ and Brantz Mayer the future philanthropist, historian and founder of the Maryland Historical Society. ${ }^{49}$ Others such as author and journalist (and occasional lawyer) John Neal would claim that they studied Hoffman's outline as soon as it became available but make no mention of actually attending Hoffman's Institute. ${ }^{50}$ No doubt Neal, like many others, took advantage of Hoffman's decision to make his outline available for sale outside of the Law Institute, thereby contributing to the contrarian situation of spreading Hoffman's fame while decreasing attendance at his Institute. 


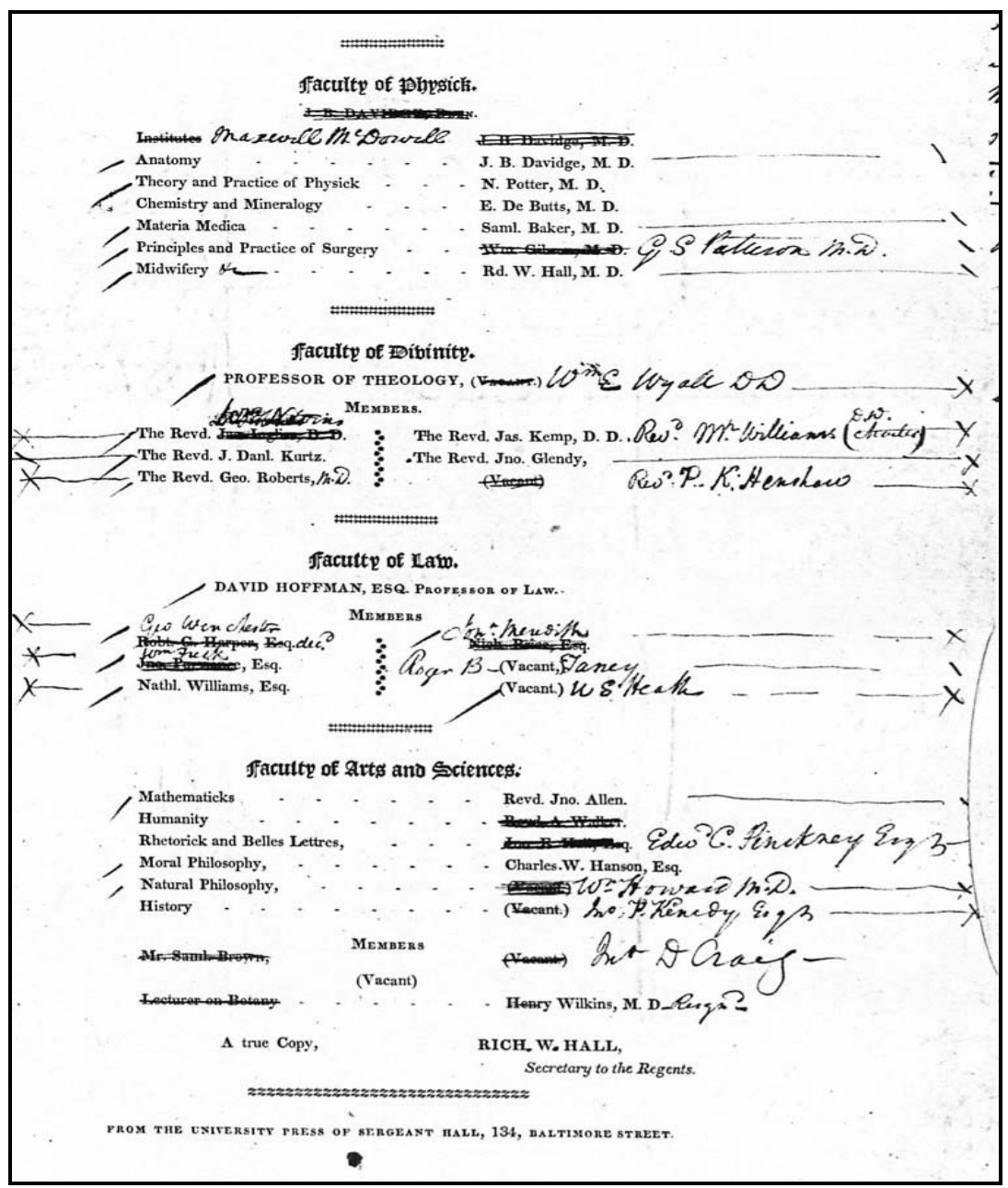

Faculty list. (The University of Maryland, Baltimore, Health Sciences and Human Services Library, Special Collections)

After leaving the University of Maryland, and between occasional visits to England, Hoffman briefly moved to Philadelphia where he published his Hints on the Professional Deportment of Lawyers, With Some Counsel to Law Students (1846). This work, which was enthustically received by the legal community, was one of the first American efforts to codify a lawyers professional conduct both generally and with specific reference to his duties to his clients and helped to cement Hoffman's role as one of the founders of an American theory of legal ethics. ${ }^{51}$ While in Philadelphia Hoffman also proposed to begin anew his efforts to teach law using a now greatly expanded version of his original method. Interestingly, Hoffman proposed to operate the school not as a university effort but as a privately-run program, an environment where he would be able to retain control of the entire undertaking. ${ }^{52}$ 


\section{Legal Career}

At the time he undertook his first teaching appointment at the University of Maryland Hoffman was already a respected member of the Baltimore bar. ${ }^{53}$ He was active before the United States District Court and the U.S. Supreme Court, handling a variety of cases, although his work seems to have focused primarily on admiralty, estates, collections and insurance issues. ${ }^{54}$

One of earliest federal cases with which Hoffman can be clearly identified, was a criminal case; the defense of three Maryland men - John Alexander, Lewis Hare, and Joseph Thompson Hare who were convicted of robbing the mail and sentenced to death. Hoffman's team included one of the leading Baltimore lawyers of the period - General William Winder. They faced considerable legal talent in the form of William Wirt, the Attorney General of the United States and Reverdy Johnson who, along with Elias Glenn, U.S. District Attorney; and Thomas Kell, represented the United States.

Among the several issues the case examined was whether the Court could proceed to trial against the defendants when the defendants, upon the advice of counsel, refused to enter a plea. Since an affirmative decision would expand the role of judges when dealing with a crime against the United States the case briefly became a cause celebre among those who opposed expansion of the judiciary's power. The case, which ultimately went against the defendants, was heard by Supreme Court Justice Duvall - in his role as Circuit Judge - and District Judge Houston. ${ }^{55}$

In 1832 Hoffman appeared before the Supreme Court as the lead attorney in an intriguing case from the Court's early period - James Sheppard and Others v. Lemuel Taylor and Others ${ }^{56}$ The case involved a suit by a group of sailors who had shipped out on the Warren for what was to have been a fairly standard merchant voyage to Canton. Once underway the ship instead proceeded to the coast of Chile to trade with the rebels involved in a revolt against Spain. The ship was seized by the Spanish Navy and the crew imprisoned. Over the course of the next four years various crew members were released by the Spanish authorities. 
Meanwhile, the ship owners had declared bankruptcy and the Warren had passed to a group of creditors, including Lemuel Taylor. The original group of sailors began an action for payment of their wages against the creditors of the Warren, who were the only people in a position to pay the wages, but who maintained that they were not responsible for the crew's back pay. ${ }^{57}$

Hoffman along with his friend and occasional associate, Charles F. Mayer, represented the surviving sailors and presented an oral argument that, in typical Hoffman style, relied on numerous cases both British and American. His counterparts before the Court, William Wirt and Roger B. Taney, likely counting on their known skills as speakers, seemed to have relied on considerably fewer authorities. ${ }^{58}$ While Hoffman and Mayer prevailed that day an appeal by Taylor would have the case back before the Supreme Court the following year. ${ }^{59}$ Hoffman, who thought the case was "endless," and probably was as frustrated as the sailors of the Warren, wrote to his friend Joseph Story in 1832 to seek some guidance in actually collecting the award from the ship's creditors:

The Bank of the US and Mr. Oliver will pay but the obstinate Quaker President of the $\mathrm{U} \mathrm{B}^{60}$ will not, as I believe, without execution, hoping to find some difficulty in making a corporation pay, as they think the only process is by attachment for contempt, and they say the creditors cannot be attached Surly [sic] there must be some process in our Courts on the nature of Fieri Facias- I have looked over the books and can get no light, but have found a note somewhat after the fashion of a Fi Fa! Can you give me some advice as the case is now forever out of your jurisdiction? ${ }^{61}$

An examination of the various reporters published in Maryland between 1812 and 1854, along with a search of the Westlaw $^{\odot}$ database, revealed only seven reported Maryland cases (listed below) in which Hoffman is clearly identified as one of the participating attorneys. ${ }^{62}$ One of these, Kalkman v. Causten, 2 Gill and Johnson 365 (1830), dealt with a historically interesting case of the ship Temperance owned by Kalkman and sunk at the entrance to Baltimore harbor in defense of Fort McHenry and Baltimore in 1814. Causten was hired by Kalkman to represent him (along with other ship owners) in Washington to seek the passage of legislation authorizing payment for the ship owners' losses. During the process of this effort Kalkman declared bankruptcy. Elias Glenn then became Kalkman's trustee and authorized the payment of Causten, if he was successful in Washington, to be paid from the money set aside by Congress. Causten was successful 
but was unable to obtain payment either from the Treasury Department or from Glenn, acting on behalf of Kalkman. For Hoffman, who represented Causten, the case involved a familiar situation namely who should be responsible for paying an attorney his fee when the client becomes insolvent? Other questions raised in the case included what instructions should have been given to the jury in the lower court (the then sixth judicial circuit of Harford and Baltimore Counties) and when exactly did Kalkman and Causten committed to the contract.

In looking at Kalkman and Hoffman's other known reported cases it is possible to get a general sense of the types of legal work that he handled.

- Hunt v. Edwards, 4 Harris and Johnson 283 (1817). H. represented the appellant. The case dealt with who is responsible for paying a promissory note and what evidence is acceptable as proof that the note had been endorsed.

- Harris v. Earle's Executors, 4 Harris and Johnson 274 (1817). H. represented the Appellees. What constitutes performance in an agreement to assign part of a judgment from one party to another, third party?

- Sloan v. Wilson, 4 Harris and Johnson 322 (1818). H. represented the Appellee. The case, among other things, dealt with who could be held responsible for paying the note of a debtor and if, the letter presented to the court as evidence of an agreement to pay the note of the debtor was sufficient to serve as an agreement.

- Owings v. Baltimore and Reister's-Town Turnpike Road, 5 Harris and Johnson 84 (1820). H. represented the appellant. Case considered if, in the meaning of the statute incorporating the turnpike, Owings lived on a tract attached to the road and thus had only to pay a toll once in any 24 hour period or if the tract was far enough removed that Owings was obligated to pay each time he traveled the road.

- Ringgold v. Ringgold, 1 Harris and Gill 11 (1826). H. represented the appelles (in part). A complicated estate case that dealt with several questions: who is responsible for paying debts of the deceased; which set of directions when the deceased died intestate are to be followed; what constitutes evidence in response to a bill.

- State, to use of Mayor, etc, and City Council of Baltmore et al. v. Boyd, 2 Gill and Johnson 365 (1830). H represented the appellant. Although initially a debt action several issues were raised before the Court but after demurrers and withdrawals the only issue remaining dealt was to determine the meaning and intent of the "limitations" in the Acts of Limitations.

At the State level Hoffman handled another important case that eventually made its way to the U.S. Supreme Court, Barron v. Baltimore. ${ }^{63}$ Hoffman along with his nephew Peter Hoffman Cruse and long time associate Charles Mayer represented John Craig and John Barron in their initial action against the Mayor and 
the City of Baltimore. ${ }^{64}$ Hoffman maintained that the City of Baltimore, by re-grading streets and alleys had caused silt to flow into the harbor above and adjacent to the wharves owned by Barron and Craig, and therefore deprived Barron and Craig of the use of their property. Therefore, they were, Hoffman reasoned, entitled to compensation. ${ }^{65}$ The Maryland Court of Appeals decided for the City and on appeal in 1833 the United States Supreme Court affirmed the decision. By the time the case was heard by the Supreme Court, Hoffman was engaged in his own struggle with the University and the Trustees and in making his plans to sail to England and likely was not available to appear before the court in Barron. ${ }^{66}$

In 1845 Hoffman, who at this time was living in Philadelphia, teamed with Mayer again, in an effort to persuade the U.S. Congress to pay the descendants of Richard S. Hackley for land in East Florida that had allegedly been appropriated by the government under the Armed Occupation Act of $1842 .{ }^{67}$ The claim was subject to some dispute as the transfer of lands from Spain to Richard S. Hackley may have been in conflict with the terms of the Adam-Onis Treaty since the transfer took place after the deadline discussed in the treaty. ${ }^{68}$ In fact, Richard Hackley and his heirs had been contesting the status of his lands in Florida since about 1820 and his protests had been continually rejected by Congress. ${ }^{69}$ It is unclear who actually wrote this second protest, Hoffman or Mayer, but it is likely that the strident tone exhibited throughout is Hoffman's. Although much shorter than other similar petitions by Hoffman, perhaps this was Mayer's influence, the overall style of the Hackley protest mirrors Hoffman's earlier, and unsuccessful, petition in 1828 to Congress on behalf of Peter Guistier. ${ }^{70}$

In addition to his law practice Hoffman was a regular contributor to the fledgling legal journals in America offering opinions on the practice of law and analyzing cases. ${ }^{71}$ Always interested in law reform, Hoffman supported the codification movement and urged the adoption of Bentham's (or Bentham-like) codes as a means of establishing a unique American system of law. ${ }^{72}$ In 1834 Hoffman was appointed to serve as the Director of the Digest of the Laws of Maryland as part of an early effort to codify Maryland law. However, 
there is little indication that he ever began this work. In 1836 the Maryland General Assembly repealed the resolution creating the Director position and withdrew the Governor's right to pay anyone serving in the position. Hoffman's response to this is lost but it is not too great a speculation that, given his penchant for writing exactly what he thought, the letter received by the Maryland Senate in 1836 did not mince any words. ${ }^{73}$ Finally, his surviving letters to Justice Story, Henry Wheaton, James Causten and fellow Marylander Virgil Maxcy all attest to Hoffman's continued relationship with his colleagues in the legal community even after he moved on to other projects. ${ }^{74}$

It is interesting though to note that Hoffman is conspicuously absent from the biography of one his Baltimore legal contemporaries, John H.B. Latrobe. Latrobe and Hoffman were briefly members of the same social club (below) and doubtlessly their paths must have crossed at some point. The absence of Hoffman from the Latrobe work probably has more to do with their respective political leanings than any personal animosity. This seems particularly likely considering the strong attachment Hoffman held to the correctness of his political views. ${ }^{75}$

\section{Politics}

Along with his legal and teaching career David Hoffman was also an active participant in both Baltimore and national politics, first as a Federalist and later as a member of the Whig party. In 1812, as a member of the Federalist Party, Hoffman, Revolutionary war hero "Light Horse" Henry Lee, local publisher (and future Maryland Congressman) Alexander Contee Hanson and several others were involved in a pitched street battle with those who supported President Madison's declaration of war. ${ }^{76}$ Hoffman and Hanson both attended St. John's College during the same period and it is likely that Hoffman became involved in Hanson's venture as much out of his devotion to the Federalist cause as he did out of his association, and shared personality traits, with Hanson. It is clear from a reading Hanson's own account of the riots that he and Hoffman both shared a temperament that could drive them on to disaster as they focused solely on the "rightness" of their cause. ${ }^{77}$ 
While it has been maintained that Hoffman was "too self-righteous" for politics he did in fact enjoy an active, albeit low profile, influence that might have grown into more had he taken a more circumspect approach. ${ }^{78}$ Hoffman's lack of skill in approaching matters political and his failure to value the social connections of American politics may be seen in his letter to John Quincy Adams in 1819 discussing the qualifications of Thomas Bland for the position of District Judge. ${ }^{79}$ While other letter writers, such as William Wirt and Supreme Court Justice Gabriel Duvall addressed only the abilities of the alternative candidate, Elias Glenn, Hoffman directly attacked Bland, and those, like the influential Marylander William Pinkney, who supported Bland:

Mr. Pinkney has, I am informed, expressed a favorable opinion of Wm. Bland. This appears to me not only irregular, but unaccountable, as Mr. Pinckney's views on all matters connected with learning and learned men are so uniformerly sound. He must, I should suppose, have perceived that an increase of Wm. Bland's knowledge has generally tended to confusion rather than illumination...Mr. P. cannot be unacquainted with his [Bland's] other deficiencies. Learning in a judge is no doubt, essential, but a little learning guided by good sense, has always been found more efficient and useful, than undigested knowledge under the direction of an imbecile mind. ${ }^{80}$

In 1841 Daniel Webster, who was then serving as Secretary of State, offered Hoffman the opportunity to serve as a Commissioner to Mexico. Had Hoffman accepted this lesser position and built upon it he might have achieved the political influence he sought. Instead he turned the offer down. ${ }^{81}$ 




Journal of the Executive Proceedings of the United States Senate, 1841. (Thurgood Marshall Law Library, Special Collections)

By the time Hoffman next sought a political appointment in the Foreign Service he had been too long out of the loop and possessed little political capital to offer an old Washington hand like Daniel Webster. Hoffman himself may have recognized this as his request for a foreign mission post is more pleading than persuasive. ${ }^{82}$ Of the two posts that Hoffman sought, Spain and Austria, the first was held by Washington Irving (1840-1846) while the second was not filled during Webster's tenure. ${ }^{83}$

Hoffman probably did not help himself in his application to Webster for the Austrian mission by citing only personal and family reasons for desiring the position while all the while maintaining that the President had "assured him" of an appointment once a position came open. ${ }^{84}$ Hoffman's approach to Webster again illustrates how his self-absorbed personality often hindered his own efforts. Convinced that he had been promised the position outright Hoffman assumed that his social position, legal training and past Whig politics 
qualified him for the appointment. All the while Hoffman was either oblivious to, or thought he was above, the "tit for tat" nature of political appointments. His inability to secure the appointment comes as no real surprise considering how poorly qualified Hoffman was, in terms of temperament, for a position that would have required a great degree of discretion. The politically astute Webster, who had worked with Hoffman in the past, probably had a greater understanding of Hoffman's abilities and shortcomings than Hoffman himself did.

\section{Author and Social Critic}

Not content with his already threefold career Hoffman embarked on a literary career penning a collection of amusing and pointed commentaries on life in America under the pen name of "Anthony Grumbler of Grumbler Hall." ${ }^{15}$ He also proposed to write a multi-volume history of the world under the title of Cartaphilus, the Wandering Jew. ${ }^{86}$ David Hoffman's literary efforts offer a view of his career that has often been overlooked. Historian Robert Ferguson suggests that Hoffman represents the type of lawyer who viewed literary efforts as important but that they should not distract from the primary purpose of legal training - creating a nation of laws. ${ }^{87}$ While this is essentially true, such a limited perspective fails to take into account the seriousness with which Hoffman approached his few literary efforts. Like Washington Irving, ${ }^{88}$ or Hoffman's fellow Baltimorean John Pendleton Kennedy, ${ }^{89}$ Hoffman hoped that by using his training and skills to respond satirically to the changes that he saw developing in American society he could re-direct attitudes and opinions. His curmudgeonly Anthony Grumbler of Grumbler Hall served as more then just an amusing (and telling) pseudonym; he was the voice for educated elites who feared that the potential greatness of the Nation was being undercut by the common ways and broad democratic participation of the 1830 s. One way this change manifested itself in Grumbler/Hoffman's view was in the loss of prestige that Hoffman thought had normally been reserved for educated lawyers:

What does the term esquire now import? If nothing, it ought to be disused- if something, it then must confer a title of some precedence. Counsellors at law, justices of the peace and aged gentleman were formally entitled to it, more by reputation than in strict right. But now, no one can venture to address a youth who has passed twenty-one, -a merchant, or even a haberdasher, without esquiring him! 
Where is this title of precedence so strangely abused as in Eromitlab [Baltimore]?-And though it can break no bones, nor pick any pockets, it is still hugely out of keeping, and strongly indicative of the "ultraism" of our democracy. Would it not be far better wholly to abolish every title of precedence, than to use them without the least discrimination? ${ }^{90}$

It is not a stretch to conclude that the resurgent outcry against trained lawyers, and in fact against all professions, increasingly common in the 1830 s, deeply offended Hoffman's aristocratic sensibilities and drove his literary ambitions. ${ }^{91}$

In 1839 Hoffman continued this theme in his work Viator: or a Peep into My Note Book wherein he compared the "sterling character of the British nation" with the "ultraism" and constant desire for change in America:

Innovation...prompts men to think that change must be improvement-but which the cautious venerators of literature, the law, and the manners of the olden times, have so often to deplore...[men] in their eagerness for change, will root up the sturdy oaks, with the noxious tares. ${ }^{92}$

Hoffman's concerns over the democratization of American society would remain virtually unchanged during his life. Although Hoffman tempered his elitist views while recruiting emigrants in the 1840s for John Fremont's California land sales, in his final non-legal work (Cartaphilus) Hoffman returned to his earlier theme urging tolerance but only within acceptable boundaries:

Only a few words more unto thee, oh Albion! - Thou mayest be either the Savior, or the Destroyer of Man's best hope on Earth, and in Heaven, - for there are in thee two signal virtues flowing from the Source of all Good - "TOLERATION" and "LIBERTY" - the just use of either of which is heavenlythe abuse of which is diabolic! .... Doubt it not, oh Albion, that the "Toleration," without conservative limitations, and thy "Liberty," without its essential restrictions, are fascinating thee into the abyss thou wouldst avoid. ${ }^{93}$

Hoffman's literary efforts, while certainly sincere, serve most effectively as a means to highlight his own elitist views and growing dissatisfaction with life in America. 


\section{MISCELLANEOUS THOUGHTS}

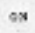

MEN, MANNERS, ANDTHINGS;



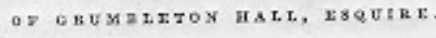



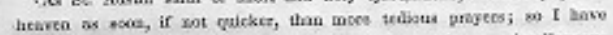

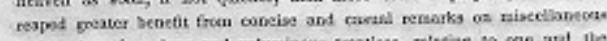

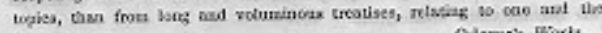
sme taing."

BOSTON:

CHALLS C. LITTIX \& JAKES HOWS.

1841.

Miscellaneous Thoughts on Men, Manners and Things. (Thurgood Marshall Law Library, Special Collections)

\section{Social \& Personal Life}

One of the few contemporary acknowledgements of Hoffman's literary efforts was an invitation to join Baltimore's "Monday Club" - a local literary and drinking society founded by John Pendelton Kennedy. ${ }^{94}$ "The Monday Club" was envisioned by its members as a successor of sorts to the "Tuesday Club" of Annapolis and claimed as members such Maryland luminaries as George Calvert, Benjamin Howard, and John Latrobe. ${ }^{95}$ Hoffman does not appear to have been invited to join an earlier literary society - the Delphian Club- to which both Latrobe and Kennedy had belonged. ${ }^{96}$

"The Monday Club" was only one of Hoffman's stops on the Baltimore social circuit. He, along with his wife Mary, were regular guests of Robert Gilmore, Dr. Ashton Alexander (Secretary of the Medical and 
Chirurgical Faculty of Maryland), and fellow Law Faculty member William Frick. ${ }^{97}$ Hoffman also served on many boards and associations in Baltimore, including the Maryland Academy of Science and Literature, where he served with Baltimore lawyer William Donaldson. ${ }^{98}$ Donaldson was, coincidentally, also one of the "investigators" employed by the State of Maryland to examine the actions of the militia following the 1812 riots. ${ }^{99}$ Hoffman was a leading supporter of the Whig Party in Baltimore and was in regular contact with many local and national Whig leaders. ${ }^{100}$ This is in addition to the many political and professional contacts in Philadelphia that he likely gained through his marriage to Mary McKean, the granddaughter of former Pennsylvania Governor Thomas McKean. ${ }^{101}$

While his marriage to Mary McKean appears to have been stable Hoffman's family life was filled with loss. Of the three children born to the Hoffman's only one daughter survived and Hoffman and his wife almost lost her as well. ${ }^{102}$ In 1833, during his struggles with the University of Maryland Trustees, his only son died and Hoffman expressed his grief and sense of loss to Joseph Story writing that "this has been a miserable day to me. A week ago I received the first confidential intelligence concerning my beloved, my only son. I was compelled to keep it to myself - I could not venture to communicate it to my wife. A day or two ago I made a partial communication of the sad news, I need not tell you how miserable we have been." 103 While the chances of losing a child through illness or accident were high in the 1830s the loss of two, almost three, would make any parent feel both beleaguered and anxious for the future. These feelings are certainly present in Hoffman's letter to Story and may account for the pleading tone of his request for a foreign mission post to Daniel Webster. ${ }^{104}$

By this time Hoffman was greatly dissatisfied with his life in the United States. Frustration over the changing nature of life in America, coupled with a dwindling interest in his legal work and fear for the health of his family led Hoffman to depart for England, intending to remain permanently. In an 1847 letter to Henry Wheaton Hoffman urges Wheaton to assist him in disposing of his unsold publications so at to not be 
burdened with them after his departure. Offering to sell the unbound sheets at $\$ 1.50$ a piece Hoffman refused to take less than $\$ 1.25$ for the remaining stock, threatening to destroy the remaining sheets himself rather than be embarrassed by such a poor showing for his work. Hoffman is determined, he tells Wheaton, to "bid adieu to the American shores." 105

\section{England and Land Speculation}

England was the scene of Hoffman's final career disappointment. After his failure to secure a foreign mission post he undertook for himself the role of a promoter for emigration to unsettled lands in the United States. He began, in typical grandiose Hoffman fashion, with a published announcement listing not only the attributes of the region he sought to promote (portions of Southern Ohio and Northern Kentucky) but also six lengthy points on why such an endeavor should be considered. ${ }^{106}$ His plan was to create a "British-American Land and Emigration Company" that would purchase land for re-sale to immigrants, draw up maps and charts and create a journal which would focus on emigration to the U.S. and finally, to sell stock in the company. ${ }^{107}$ The scheme was, even for Hoffman, unusually audacious, and depended in part not only on investors accepting his proposals but also on the State of Ohio somehow gaining control of a substantial portion of land in northern Kentucky. ${ }^{108}$

Hoffman's pamphlet affords insight into his changing views: on the issue of slavery Hoffman seemed to have adopted the belief, common among many Americans that left to its natural course free labor would put an end to slavery. ${ }^{109}$ With respect to the "leveling of society" Hoffman, who had encouraged only the participation of "gentlemen" in his scheme, also urged those who considered moving to the western lands to leave their sense of class or position behind:

It is especially observed that no one should think of settling in the United States who is attached to English social distinctions and who is disinclined toward democratic institutions and their natural consequences. Everyone before making up his mind to join this company should take the trouble to become acquainted with the character of the climate, the condition of the country and the state of the society. ${ }^{110}$

Whether this truly represents a genuine change in Hoffman's views or was merely an effort to attract as many 
investors as possible to his plan is not clear. Whatever the motivation, it is a public departure from the view he advocated years before in Men, Manners and Things. ${ }^{111}$

Hoffman's finances and schemes took yet another downward turn in 1851 when he became the sole British agent involved in an effort to sell land in California that had been purchased and mapped by John C. Fremont. ${ }^{112}$ As demand for this California land increased Hoffman became involved in a public newspaper battle with a competitor that was so embarrassing to Fremont, and so disruptive to efforts to sell the land, that Hoffman was relieved of position as Fremont's agent. ${ }^{113}$ An open letter in the London Times from Hoffman to John Duncan, the attorney for Thomas Sargent who claimed to control some of the land Hoffman was trying to sell, again exemplifies Hoffman's personal and aggressive style in his dealings with the many claimants to Fremont's land in California.

Letter to John Duncan, Esq.* 10 Conduit Street, 1st March, 1852.

Sir - In reply to your note of the 28 th, received this morning I have to state as follows:-

1st. I cannot at all admit that I was in the least benefited by the perusal of the copies you permitted me to see, only by the unavoidable compulsion of your case; but I acknowledge freely your courteous manner whilst I was examining them.

2nd. I regard then, and much more now, your situation as most eminently perilous.

3rd. Sargent, I repeat, is not the purchaser of an inch of the Mariposas.

4th. He never will be.

5th. He has been the architect of his own certain ruin, and of the sure disgrace of many.

6th. Your suits against me for Sargent, and also for the ridiculous Mr. Green, are nuts for me to crack hereafter. Proceed with them at your and their peril.

7th. My powers and numerous letters are not to be inspected by you. Hundreds have seen them and fully. That is for me quite sufficient.

8th. The horrible contrivance will come out in due time. I know it all--all.

9th. You cannot, I fear, duly appreciate your own dreadful condition, and my own strict adherence to justice, and my total indifference to all motives, save those of rigid truth.

10th. I have no vengeance in my nature; but Sir, do not, for your own sake, press me further. 
11th. You are a man of talents (so say all), but talents alone will serve no man.

12th. Write me no more notes; I have neither inclination nor time to even read them--certainly not to reply to them.

13th. My previous information between the 24th of February and this 1st of March was complete.

14th. My letters received this 1st of March, 1852, are more than ample for me and for the public, here and in the United States, and as to which you and they will hear in due season.

I am, Sir, your most obedient servant, David Hoffman

Unfortunately for Hoffman, Fremont was not completely truthful in his dealings with his London Land Agent. John Fremont was, throughout this period, selling (and even giving) land to his father-in-law, Thomas Benton. Benton, in turn, was selling the land to others oftentimes in conflict with Hoffman's efforts. This would eventually leave Hoffman, not discounting his own aggressive approach, in a professional and financial bind. Dismissed by Fremont and unable to secure much support for his own Ohio plans, Hoffman reluctantly returned to the United States where, upon arriving in New York, he died quite suddenly. ${ }^{114}$

\section{Final Thoughts}

David Hoffman, committed to his profession and the idea of America as a nation of laws, devoted his life to reforming the legal community through education, codification and his own personal example. In fact, Hoffman lived the type of life and career that, according to Robert Ferguson, many of his contemporaries sought after. ${ }^{115}$ Yet throughout his life Hoffman proved to be self-centered, short-sighted and, in many ways, his own worst enemy. Oftentimes Hoffman failed to realize that what he felt was his due, because of social position and training, his contemporaries saw only as inflated vanity. While Hoffman did contribute to the creation of a "Republican Culture," as suggested by Professor Maxwell Bloomfield, the resulting society was hardly one that Hoffman would have embraced as his own. ${ }^{116}$

Hoffman's death in 1854 warranted only one brief paragraph in the Baltimore Sun. ${ }^{117} \mathrm{He}$ had, in the years since his move to England, become increasingly isolated from the American legal community. Although his 1817 outline continued to serve as a guide for scholarly lawyers, ${ }^{118}$ the law itself had undergone 
fundamental changes by mid-century. ${ }^{119}$ No longer was the legal system the domain of an educated elite. Instead, it had become primarily a craft performed by competent but increasingly narrowly trained practitioners. ${ }^{120}$ That Hoffman was either unaware of this shift or unwilling to endorse it is reflected in the

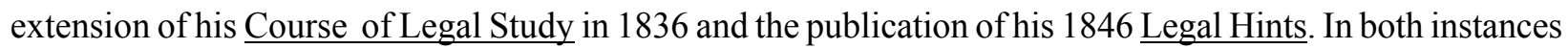
Hoffman's belief that the needs of practicing attorneys would best be answered by philosophical works that could assist them in their future education and scholarship was at odds with the growing demand for "practical" publications that by mid-century represented the bulk of legal publishing in America. ${ }^{121}$

While Hoffman's personal ideals did not keep pace with changes in the law his theories on how to teach the law were not a complete failure. For example, there are echoes of Hoffman's methodology in the early curriculum design of both Benjamin Butler's program at New York University ${ }^{122}$ and Joseph Story's early efforts at Harvard University. ${ }^{123}$ Hoffman's method for training lawyers even served, in an age before bar exams, as a model for evaluating the quality of would be attorneys in states as far away as Louisiana and Alabama. ${ }^{124}$ That Hoffman's influence continues to be felt can be seen in the more recent claims for him as the "father of American legal ethics." 125 Today the legal community can look to this dynamic Maryland scholar as the founder of a multi-disciplinary academic model that remains central to the mission of many contemporary law school programs. ${ }^{126}$ 


\section{Appendix}

\section{David Hoffman Time Line}

1784 December 24 - David Hoffman born.

1802 - Hoffman attends Saint John's College in Annapolis, Maryland.

$1802-1804 ?$ - Legal training.

1812 - The University of Maryland Chartered.

1812 - Hoffman and others involved in riot and street battles over President Madison's declaration of war.

1813 - An Act to Authorize the Raising a Sum of Money by a Lottery or Lotteries to Build an Arsenal for the City of Baltimore, and for other purposes.

1814 - Receives appointment as Professor of Law at the University of Maryland.

1816 January - Marries Mary McKean of Philadelphia, PA.

1816 November - Son Frederick is born.

1817 - A Course of Legal Study is published.

1818 November - Daughter Anne McKean is born.

1818 May - Argues (as co-counsel representing the defendants) United States v. Hare in the Circuit Court of Maryland.

1819 March - Daughter Anne dies.

1822 - Appears before the U.S. Supreme Court in The Arrogante Bacelones.

1822 - Appears before the U.S. Supreme Court in The Santa Maria.

1822 - Hoffman announces in the American Commercial \& Daily Advertiser the start of his program, which he calls a "Law Institute," at the University of Maryland.

1823 - Hoffman begins publishing his University lectures in pamphlet form.

1824 - Publishes An Address to Students of Law.

1826 - Appears before the U.S. Supreme Court in Chace against Vasquez.

1828 - Publishes Memorial and argument in the case of the ship Blaireau, praying a return of tonnage and duties, erroneously paid in 1803: addressed to the Senate of the United States. (Guistier petition)

1828 - Appears before the U.S. Supreme Court in Benjamin Buck \& Thomas Hendrick v. The Chesapeake Insurance Company.

1829 - Petition on behalf of Peter Guistier rejected by the United States Congress.

1830 - Argues Kalkman vs. Causten in the Maryland Court of Appeals.

1830 - The Construction of a Power of Attorney, and of a Deed by Hoffman published in the American Jurist \& Law Magazine.

1830 - Appears before the U.S. Supreme Court in James Sheppard v. Lemuel Taylor ("Warren I") .

1832 - Hoffman announces his intention to close the "Law Institute" at The University of Maryland.

1832 - Appears before the U.S. Supreme Court in Robert Oliver v. James Alexander and Seventy-seven others, Seamen of the Warren ("Warren II").

1833 - Hoffman's son Frederick dies. 
$1833 ?$ - Hoffman travels to England.

1836 - Revises A Course of Legal Study, published in both Baltimore and London.

1837 - Writing as "Anthony Grumbler" Hoffman publishes Miscellaneous Thoughts on Men, Manners and Things.

1839 - VIATOR; Or, A Peep Inside My Notebook published.

1839 - Helps University faculty to prepare a statement to the Trustees on the possible take over of the University by the State of Maryland.

1840 - Serves as Presidential Elector for Harrison.

1841 - Publishes second edition of Miscellaneous Thoughts.

1843 - University Trustees formally accept Hoffman's resignation from the University of Maryland.

1843 - Hoffman seeks foreign mission post from Secretary of State Daniel Webster, expresses an interested in either Austria or Spain.

1844 -1847 - Conducts a private law school in Philadelphia, PA.

1845 - Publishes The Second Protest of Richard S. Hackley's heirs, respecting their lands in east Florida: addressed to his Excellency James K. Polk, President of the United States: June 27, 1845.

1846 - Hints on Professional Deportment of Lawyers, With Some Counsel to Law Students published.

1847 - Moves to England.

1847 - Writes series of articles on life in America for The London Times.

1848 - Views on the Formation of a British and American Land and Emigration Company published.

1849 - Letter by an American Citizen, Permanently Resident in England Addressed to British Capitalists published.

1850 - 1851- Employed by John C. Fremont to help sell land in California.

1853 - Publishes volume one of Chronicles Selected from the Originals of Cartaphilus, the Wandering Jew Embracing a Period of XIX Centuries.

1854 - Returns to the United States, dies in New York City. 


\section{Notes}

- Bill Sleeman, MLS, MA. Assistant Director for Technical Services, Thurgood Marshall Law Library, the University of Maryland School of Law. 501 West Fayette St., Baltimore, Md. 21201. Telephone: 410-706-0783 Email: bsleeman@law.umaryland.edu.

The author would like to thank Professors Andy King and Garrett Power of the University of Maryland School of Law and Rich Behles, Historical Librarian, Health Sciences and Human Services Library, The University of Maryland, Baltimore for their careful reading of earlier drafts and their many helpful suggestions. The author also thanks Pamela Bluh, Associate Director for Technical Services, Thurgood Marshall Law Library for her support throughout this project. Errors of fact and analysis are the sole responsibility of the author.

1. Thomas L. Shaffer, "David Hoffman's Law School Lectures, 1822 - 1833,” Journal of Legal Education, 32 (1982): 127. ; Maute, Judith L. "Changing Conceptions

of Lawyer's Pro Bono Responsibilities: From Chance Noblesse Oblige to Stated Expectations,” Tulane Law Review, 77 (2002-2003): 103.

2. Maxwell Bloomfield, "David Hoffman and the Shaping of a Republican Legal Culture," Maryland Law Review, 38 (1979): $678-679$.

3. Anthony Grumbler, Miscellaneous Thoughts on Men, Manners, and Things, (Baltimore: Published by Coale \& co., 1837). Thurgood Marshall Law Library, Special

Collections, The University of Maryland School of Law.

4. Wilbur S. Shepperson, "Thomas Rawlings and David Hoffman: Promoters of Western Virginia Immigration," West Virginia History, 15 (1954): 311.

5. David Hoffman, A Course of Legal Study; Respectfully Addressed to the Students of Law in the United States (Baltimore: Published by Coale and Maxwell, 1817).

Thurgood Marshall Law Library, Special Collections, The University of Maryland School of Law.

6. David Hoffman, Chronicles Selected From the Originals of Cartaphilus, The Wandering Jew Embracing a Period of Nearly XIX Centuries (London: T. Bosworth,

1853). Maryland State Law Library.

7. Two articles that look at Hoffman's legal career provide and provide biographical information are: Bloomfield, "David Hoffman and the Shaping of a Republican

Legal Culture," note 2 and Shaffer, "David Hoffman's Law School Lectures," note 1.

8. Whitman H. Ridgway, Community Leadership in Maryland, 1790 - 1840 (Chapel Hill: The University of North Carolina Press, 1979). Mary A. Seitz, The History of the Hoffman Paper Mills in Maryland (Towson: The Holliday Press, 1946), 24-26.

9 Ridgway, Community Leadership in Maryland, 1790 - 1840. Also, Bloomfield, "David Hoffman," 675. Descendants of William Hoffman. Unpublished typescript.

Library of the Baltimore County Historical Society.

10. Bloomfield, "David Hoffman," 674.

11 Konefsky, Alfred S. and King, Andrew J. The Papers of Daniel Webster: Legal Papers, Volume 1 - the New Hampshire Practice. (Hanover, N.H.: University Press

of New England, 1982). See chapter 1 generally for Webster's and others dissatisfaction with content and nature of legal education as an apprentice. 
12. The nature of legal education in Maryland, like legal education across the United States, was extremely varied in the opportunities that were available to students. A very good discussion of the type of training afforded most attorneys can be found in John E. Semmes, John H.B. Latrobe and His Times (Baltimore: The Norman, Remington Co., 1917), 100.

13. Bloomfield, "David Hoffman," 675.

14. Dumas Malone, Editor, "David Hoffman," Dictionary of American Biography, (New York: Charles Scribner's Son, 1932), 5:111. (hereafter DAB)

15. David Hoffman, A Course of Legal Study.

16. DAB 5:111. See also, Shaffer, "David Hoffman's Law School Lectures," 127.

17. Hoffman, Course of Study, xi - xii.

18. Paul D. Carrington, "The Revolutionary Idea of University Legal Education," William \& Mary Law Review, 31 (1990): 527.

19. Hoffman, A Lecture being the second of a series of lectures introductory to a course of lectures now delivering in the University of Maryland. (Baltimore: John Toy, $1825), 2$.

20. Charles M. Cook, The American Codification Movement: A Study of Antebellum Legal Reform (Westport: Greenwood Press, 1981 ), 61.

21. Hoffman, Course of Study, xv.

22. Ibid.

23. Ibid., xvii.

24. Ibid., $\mathrm{xxx}$.

25. Ibid., 273.

26. DAB, 5:111.

27. An Act to Authorise the Raising a Sum of Money by a Lottery or Lotteries to Build an Arsenal for the City of Baltimore, and for Other Purposes, Chapter 125 . The Laws of Maryland, From the End of the Year of 1799 (Annapolis, 1813).

28. Bernard C. Steiner, "History of Education in Maryland," Contributions to American Educational History (Washington: Government Printing Office, 1895$), 136$. Also identified as United States Bureau of Education, Circular of Information, No. 2, 1894.

29. Among researchers there is some difference of opinion as to when Hoffman actually began his Institute at the University. The DAB gives a date of 1823 , while Shaffer and Bloomfield both cite 1822 as the first year that Hoffman began to lecture using his method. Bernard Steiner in an 1894 report to the U.S. Bureau of Education writes that Hoffman announced his program in the American \& Commercial Daily Advertiser in 1822 but did not begin actual instruction until 1823. 
Hoffman's own records - in his letter to the Trustees of the University claims to have begun in 1822 and it is this date, from his own writing, that I have accepted as the "official" date for his Institute to have begun.

30 See: David Hoffman, The Trustees of the University of Maryland in relation to the law chair. (Baltimore: J.D. Toy, 1826). Maryland Historical Society.

31. "Minutes of the Faculty of the University of Maryland," September 21, 1821. The University of Maryland Health Sciences and Human Services Library, Special

Collections, The University of Maryland, Baltimore.

32. Ibid.

33. George H. Callcott, A History of the University of Maryland (Baltimore: Maryland Historical Society, 1966), 55.

34. Ibid. $72-75$.

35. Hoffman, David. A Circular to Students at Law in the United States. Philadelphia: Barrett and Jones, Printers, 1844. The Making of Modern Law. Thomson-Gale, 2004. (viewed 11/01/2004). http://www.galegroup.com/ModernLaw/

36. Calcott, History of the University of Maryland, 69.

37. "A Letter to the Trustees," 1826. Minutes of the Faculty, 1839. The University of Maryland Health Sciences and Human Services Library, Special Collections, The University of Maryland, Baltimore.

38. Hoffman did prepare a series of open letters to the Trustees expressing his concerns over finances, competition with the medical faculty, and the overall structure of the law institute, concerns which apparently were never addressed to his satisfaction. David Hoffman, To the Trustees of the University of Maryland in relation to the law chair. (Baltimore: J. D. Toy, 1826). Maryland Historical Society.

39. Letter to the Trustees. 38 above

40. Calcott, History of the University of Maryland, 37.

41. An Act Regulating the Admission of Attorneys to Practice Law in the Several Courts of this State, Chapter 286. Laws Made and Passed by the General Assembly of the State of Maryland (Annapolis, 1832). One part of this law allowed attorneys to practice with only two years of education, considerably less than what Hoffman believed was necessary if a student was to be an able lawyer.

42. An Act limiting the time for the collection of the Fees of Attorneys, Solicitors, Clerks, Registers, Sheriffs and other officers of the State, Chapter 258. Laws Made and Passed by the General Assembly of the State of Maryland (Annapolis, 1834). The Act limited to three years the amount of time in which an attorney could try to collect any fees. Also, Letter to the Trustees at 38 above. 
43. Calcott, History of the University of Maryland, 68.

44. Ibid.

45. An Additional Supplement to the Act, Entitled An Act for the Benefit of the University of Maryland, Chapter 270. Laws Made and Passed by the General Assembly of the State of Maryland, (Annapolis, 1832). This law allowed a group of medical faculty, including Nathaniel Potter, to bring an action against the Trustees for the reimbursement of personal funds expended on behalf of the University.

46. David Hoffman, A Course of Legal Study, Addressed to Students and the Profession Generally, (Baltimore: Published by Joseph Neal, 1836). Thurgood Marshall Law Library, Special Collections, The University of Maryland School of Law.

47 Faculty list. Records of the University of Maryland. Health Sciences and Human Services Library, Special Collections. The University of Maryland, Baltimore. 48 Eugene Cordell, University of Maryland, 1807-1907. (New York: The Lewis Publishing Co., 1907). volume 2, p.7

49 Dumas Malone, Editor, "Brantz Mayer," Dictionary of American Biography, (New York: Charles Scribner's Son, 1932 ), 6: 449.

50 John Neal, Wandering Recollections of a Somewhat Busy Life: an autobiography. Boston: Robert Brothers, 1869 . p. 167.

51. David Hoffman, Hints on Professional Deportment of Lawyers, With Some Counsel to Law Students (Philadelphia: Thomas, Cowperthwait, 1846). See also:

Thomas L. Shaffer, "David Hoffman's Law School Lectures, 1822 - 1833,” Journal of Legal Education, 32 (1982): 127. ; Maute, Judith L. “Changing Conceptions of Lawyer's Pro Bono Responsibilities: From Chance Noblesse Oblige to Stated Expectations,” Tulane Law Review, 77 (2002-2003): 103.

52. Eugene Cordell, University of Maryland, 1807-1907. (New York: The Lewis Publishing Co., 1907), 347.

53. Bloomfield, "David Hoffman," 683.

54. See: Chace against Vasquez, 24 U.S. 429 (1826), The Arrogante Barcelones, 20 U.S. 496 (1822) and Chirac v. Reinecker, 27 U.S. 612 (1829); also, Peter Gustier, Memorial and argument in the case of the ship Blaireau, praying a return of tonnage and duties, erroneously paid in 1803 : addressed to the Senate of the United States (Baltimore: J.D. Toy, 1826).

55 Trials of the mail robbers, Hare, Alexander and Hare. With the testimony, the proceedings of the court, and the arguments of counsel at length. William Wirt, esq., attorney general of the United States; Elias Glenn, esq., district attorney; Thomas Kell and Reverdy Johnson, esqs., for the prosecution. General Winder, David Hoffman, Charles Mitchell and Ebenezer L. Finley, esqs. for the prisoners. Reported by Edward J. Coale. To which is added, the trial and proceedings before the Circuit of the United States, in Philadelphia, in the case of William Wood, an accessary [sic.] before the fact. Reported for the Franklin gazette, by Richard Bache, esq. (Baltimore: Edward J. Coale, 1818)..Maryland Department, Enoch Pratt Free Library. 
56. James Sheppard v. Lemuel Taylor, 30 U.S. 675 (1831). Robert Oliver v. James Alexander and seventy-seven others, Seamen of the Warren, 31 U.S. 143 (1832).

57. Sheppard v. Taylor, 30 U.S. 675.

58. Ibid.

59. Oliver v. Alexander, 31 U.S. 143.

60. Here Hoffman refers to the Union Bank in Baltimore; one of Andrew Jackson's "pet banks," whose President at the time was Thomas Ellicott. See, Richard Walsh and William Lloyd Fox, Ed. Maryland: A History, 1632-1974 (Baltimore: Maryland Historical Society, 1974), 271.

61. David Hoffman, "Letter to Joseph Story," 1832. Joseph Story Papers, The Massachusetts Historical Society.

62 This effort recognizes that there may be many more cases which did not reach court that Hoffman might be associated with. Many of these are in the records of Baltimore County and are available at the Maryland State Archives.

63 Barron v. Baltimore, 32 U.S. (7 Pet.) 243 (1833). The case, familiar to most constitutional law scholars, was one of the last decided by the Marshall Court and dealt with the application of the 5 th Amendment to individual states.

64 Descendants of William Hoffman. Unpublished typescript. Library of the Baltimore County Historical Society.

65 Records of cases decided in the Supreme Court of the United States at January term, 1833. National Archives and Records Administration. Microfilm edition.

66 "Letter to William Sullivan, Feb. 13, 1833." The Pierpont Morgan Library, New York. 1833-0214.

67 Armed Forces Occupation Acts. 5 Stat. 502. Chap. 122 (August 4, 1842).

68 Treaty of Amity, Settlement and Limits between the United States of America and His Catholic Majesty. 8 Stat. 252 (Feb. 22, 1819).

69 [David Hoffman]. The Second Protest of Richard S. Hackley's Heirs, respecting the lands in East Florida, Addressed to His Excellency James K. Polk, President of

the United States. June 27, 1845 (S.1: s.n., 1845). George Peabody Library, Johns Hopkins University.

70 Memorial and argument in the case of the Ship Blaireau, praying a return of tonnage and duties erroneously paid in 1803: Addressed to the Senate of the United

States. (Baltimore: Printed by J.D. Toy, 1826).

71. [David Hoffman], "Construction of a Power of Attorney, and of a Deed," American. Jurist \& Law Magazine, 3 (1830): 52.

72. Cook, Codification Movement, 72.

73 Journal of the Proceedings of the Maryland House of Delegates, March 17, 1837, pp.675-677, 722. Journal of the Proceedings of the Senate of Maryland, 1836. p.

44 (Index).

74. "Letter to Joseph Story," 1832. "David Hoffman. Massachusetts Historical Society Library. “ Letter to Henry Wheaton,” 1847. The Pierpont Morgan Library. 
Ma995.

75. John E. Semmes, John H.B. Latrobe And His Times, 1803-1891, 366-367. Hoffman was a committed member of the Whig party while Latrobe is quoted as being a

supporter of Jackson.

76.Robert J. Brugger, Maryland: A Middle Temperament, 1634-1980 (Baltimore: Published by The Johns Hopkins University Press, in Association with the Maryland

Historical Society, 1986), 178.

77 Alexander Contee Hanson. To the Voters of the Congressional District composed of Montgomery and Part of Frederick. [Frederick, Md.,1812?]. Maryland

Department, Enoch Pratt Free Library.

78. For example - in 1840 Hoffman served as a Presidential Elector for William Henry Harrison. Cordell, University of Maryland, 347. Calcott, History of the

University of Maryland, 35 .

79 Peter Graham Fish. Federal Justice in the Mid-Atlantic South: United States Courts from Maryland to the Carolinas, 1789-1835. (Washington, DC :

Administrative Office of the United States Courts, 2002), 225-229.

80 Hoffman, David. Letters of Application and Recommendation During the Administration of James Monroe, 1817-1825. Record group M439, roll 7, at 568-571.

National Archives of the United States.

81. Harold D. Moser, Editor, The Papers of Daniel Webster, Correspondence, 1840-1843. (Hanover: Dartmouth College, University Press of New England, 1982), 5:

412. The letter is mentioned in the calendar of 1841.

82. David Hoffman, "Letter to Daniel Webster," Feb. 1, 1843. Microfilm version of the Papers of Daniel Webster. The Library of Congress, Special Collections.

83. For a discussion of Daniel Webster's various appointments see volume one, series three of The Papers of Daniel Webster, Diplomatic Papers (1841-1843).

84. Ibid.

85. Anthony Grumbler, Miscellaneous Thoughts on Men, Manners, and Things. Thurgood Marshall Law Library, Special Collections, The University of Maryland

School of Law.

86. David Hoffman, Chronicles Selected From the Originals of Cartaphilus. See also: Syllabus of a course of lectures upon ecclesiastical and civil history during the

first ten centuries, upon a plan ... based upon the first three volumes in manuscript, of a work entitled "Chronicles of Cartaphilus." Baltimore: John D. Toy, 1841.

Maryland Historical Society.

87. Robert A Ferguson, Law and Letters in American Culture (Cambridge: Harvard University Press, 1984), 91-92.

88. Washington Irving, A History of New York (1809), Ed. Michael L. Black and Nancy B. Black (Boston: Twayne Publishers, 1984). 
89. John Pendleton Kennedy, Swallow Barn; or, A Sojourn in the Old Dominion (1832), with an Introduction by Lucinda H. MacKethan (Baton Rouge: Louisiana State University, 1986).

90. Grumbler, Miscellaneous Thoughts, 35 .

91. The outcry against learned professions and lawyers in particular was not new. The dislike for attorneys began almost as soon as colonist arrived and never really ceased although its intensity may have ebbed and flowed. See: Maxwell Bloomfield, American Lawyers in a Changing Society, 1776-1876, (Cambridge: Harvard University Press, 1976). How accurate Hoffman's interpretation of anti-lawyer sentiment was is difficult to gauge but there can be no doubt that Hoffman, writing as Grumbler, believed it to be very real.

92. David Hoffman, VIATOR: or, A Peep into My Note Book (Baltimore: Plaskitt \& Cugle, 1839), vi.

93. David Hoffman, Chronicles Selected From the Originals of Cartaphilus.

94. Hoffman was not invited to be a founding member of the Club. It is likely that it was more for his prestige in Baltimore, which was still considerable, rather than his skills as an author that eventually engendered the invitation. John Pendleton Kennedy, in commenting on Hoffman's Cartaphilus said, "I would not be surprised if it be all ready for the press in huge and painful volumes...with immense resource of reading and authority scattered through voluminous notes." Bloomfield, "David Hoffman," 686.

95. William D. Hoyt, Jr. "The Monday Club," Maryland Historical Society Magazine, 49 (1954): 301.

96 Uhler, John Earle. “The Delphian Club,” Maryland Historical Society Magazine, 20 (1925): 305.

97. "The Diary of Robert Gilmore," Maryland Historical Society Magazine, 17 (1922): 241.

98 Laws of Maryland, Chapeter 123. 1826.

99 The personal library of Donaldson, which contains a gift book from Hoffman, became - through the gift of Maryland Judge Brune - the core of the Thurgood

Marshall Law Library's rare book collection

100. Along with those already mentioned Hoffman was known to have been communication with William Henry Harrison and Henry Clay. The latter was prevailed upon to put in a word or two on Hoffman's behalf when he sought the foreign mission position from Webster. See: Robert Seager II, Editor, Melba Porter Hay, Assoc. Ed. The Papers of Henry Clay, The Whig Leader, January 1, 1837 - December 31, 1843 (Lexington: The University Press of Kentucky, 1988 ), 9: 458.

101. DAB.

102. Ibid. 
103. David Hoffman, "Letter To Joseph Story," July 18, 1833. Joseph Story Papers, The Massachusetts Historical Society.

104. David Hoffman, "Letter to Daniel Webster," Feb. 1, 1843. Microfilm Version of the Papers of Daniel Webster. The Library of Congress, Special Collections.

105 “Letter to Henry Wheaton,” 1847. The Wheaton Papers. The Pierpont Morgan Library.

106. David Hoffman, Letter By An American Citizen, Permanently Resident in England, Addressed to British Capitalists (London: John Miller, 1849). The George

Peabody Library, Johns Hopkins University.

107.Wilbur S. Shepperson, "Thomas Rawlings and David Hoffman," 316.

108. Hoffman, Letter By An American Citizen, 8.

109. Ibid. 5. For a discussion of the inconsistencies in this position see: Samuel Olken, Chief Justice John Marshall and the Course of American Constitutional

History. John Marshall Law Review, v. 33, no. (summer, 2000) at note 175.

110. Ibid. 16 .

111. Anthony Grumbler, Miscellaneous Thoughts on Men, Manners, and Things, (Baltimore: Published by Coale \& co., 1837).

112. Shepperson, "Thomas Rawlings and David Hoffman," 319.

113. Ibid.

114.DAB

115 Ferguson, Robert A. “The Emulation of Sir William Jones in the Early Republic,” The New England Quarterly, v. 52, no. 1 (March, 1979).

116. Bloomfield, "David Hoffman."

117. Baltimore Sun, Vol. 35, No. 154 (Nov. 13, 1854), page 2, column 1.

118. Ferguson, Law and Letters in American Culture, 29.

119. Ferguson, Part III. See generally, Morton Horowitz. The Transformation of American Law, 1780 - 1860 (Cambridge: Harvard University Press, 1977).

120. Ferguson, 201.

121. Examples of publications representing the antithesis of Hoffman's ideals include John Collyer's A Practical Treatise on the Law of Partnership (1848); Isaac

Redfield's A Practical Treatise Upon the Law of Railways (1858); David Graham's A Treatise on the Law of New Trials in Cases Civil and Criminal (1855); and Isaac

Edwards' A Treatise on Bills of Exchange and Promissory Notes (1857).

122. Ronald L. Brown, Editor, The Law School Papers of Benjamin F. Butler, New York University School of Law in the 1830's. (New York: Greenwood Press, 
1987). Brown provides a detailed discussion of both similarities and departures from Hoffman's ideals.

123. Bloomfield, "David Hoffman," 686.

124. Warren M. Billings, "A Course of Studies: Books That Shaped Louisiana Law" (unpublished manuscript - made available through the courtesy of Professor

Billings); Carol Rice Andrews, et. al, “Gilded Age Legal Ethics: Essays on Thomas Goode Jones' 1887 Code and the Regulation of the Profession. (Tuscaloosa,

Alabama: Occasional Publications of the Bounds Law Library, 2003).

125. Shaffer, "David Hoffman's Law School Lectures," at 127.

126. University of Maryland School of Law, Maryland Law, Embracing the Real World, 1997 Admissions Information 5. In describing the goals of the program the

Law School takes a very Hoffman-like stance on legal education - "Courses exploring the relationship between law and other disciplines reflect the faculty's view of the

importance of a good lawyer's perspective on the law. Among these disciplines are the humanities, social science, health care policy, environmental policy, economic development and others." 